\title{
GALLEON ANXIETY: How Afro-Mexican Women Shaped Colonial Spirituality in Acapulco
}

\begin{abstract}
Acapulco became a global town during the early seventeenth century, characterized not only by transpacific trade, but also by an increasingly large Afro-Mexican population residing and laboring at the port. A cohort of Afro-Mexican women gained prominence and visibility by delivering accurate predictions on the arrival of galleons to Acapulco. They adapted mixed African and Indigenous divination practices to calm port residents worried about galleon losses on the world's largest ocean. Scholarship on the Spanish Pacific has yet to investigate how the globalization of New Spain through galleon travel affected African and Afro-descendant communities. This article contends that the dangers of Pacific travel, and anxieties about them, frequently exceeded the therapeutic capacities of Catholic dogma. Black women, drawing on the profound West and West Central African estimation of female diviners, practiced clairvoyance to report on the location of galleons and whether they would arrive safely. The confluence of an increasing population of Afro-Mexicans with the economic dynamism of transpacific trade transformed spiritual life at the eastern node of Spain's Pacific empire. Black women positioned themselves at the center of these massive structural transformations and ultimately created new cultures as spiritual authorities in Acapulco.
\end{abstract}

KEYWORDS: Pacific, Africans, spirituality, divination, women

\begin{abstract}
A
capulco, the deep-water haven of the South Sea, became a global town after 1570 and the regular arrival of the Manila Galleons from the Philippines. Once the ships anchored, launches from the beach ferried the ragged, land-starved crews ashore, along with hundreds of crates of East, Southeast, and South Asian wares. This influx of Asian goods and peoples was quickly dispersed throughout the region and, by the turn of the seventeenth century, became ubiquitous in every urban center in central Mexico, as well as many others further afield. Scholarship on the galleons has credited them with enacting processes of early modern globalization through trade and, more
\end{abstract}

\footnotetext{
I extend a sincere thanks to all those without whom this article could not have been written. I especially thank William Luis, Sherri Cummings, and Catie Peters, who carefully read earlier versions of the work. I would also like to recognize the scholarly community at the John Carter Brown Library where I began conceptualizing the project during a J. M. Stuart Fellowship in 2019-20. Further, Ivor Miller provided key direction regarding the scholarship on West and West Central African religiosity. Finally, I am grateful for the rigorous and enriching comments, questions, and suggestions of the anonymous reviewers.
} 
recently, as facilitating the first Asian mobilities to and within the Americas via enslavement and free migration. ${ }^{1}$

Early modern travel writers were keenly aware, though, that the port itself failed to live up to its global reputation. Italian traveler Giovanni Gemelli Careri landed in Acapulco at the end of the seventeenth century and wrote:

Regarding the city of Acapulco, it seems to me that it should be given the name of humble hamlet of fishers (so low and contemptible are its houses, made of wood, mud and straw) than the deceitful [name] of the main emporium of the South Sea and way station to Asia. . . There do not reside in it more than negros and mulatos (those born of Black men and white women) and rarely a local Native is seen. ${ }^{2}$

Gemelli Careri's anxieties over the physicality and blackness of Acapulco contrasted with his expectations of a town connecting Asia to the Americas. It was precisely the port's demographics, though, that made Acapulco's intellectual and spiritual communities truly global in ways that Gemelli Careri did not notice. In fact, colonial-era writers did not conceive of the port's Black population as creatively and meaningfully engaged with the global connectedness of New Spanish society. Contemporary understandings of the proto-modern characteristics of transpacific trade have similarly and systematically excluded the energetic and non-dogmatic spiritual understandings of the world that typified life at the port during the early seventeenth century. This article brings to light gendered Afro-Mexican spirituality as a heretofore unidentified aspect of New Spanish culture that quickly reorganized around the daily realities of long-distance transpacific trade.

Global histories have traditionally and notoriously neglected the roles of marginalized peoples and cultures in shaping and connecting the early modern world. ${ }^{3}$ Not only has the African and Afro-descendant population been consistently undercounted in the Spanish Pacific, but it also has been excluded

1. Arturo Giráldez, The Age of Trade: The Manila Galleons and the Dawn of the Global Economy (Lanham, MD: Rowman \& Littlefield, 2015); Rubén Carrillo Martín, Las gentes del mar Sangley (Mexico City: Palabra del Clío, 2015); and Tatiana Seijas, Asian Slaves in Colonial Mexico: From Chinos to Indians (New York: Cambridge University Press, 2014). Diego Javier Luis, "Diasporic Convergences: Tracing Knowledge Production and Transmission among Enslaved Chinos in New Spain," Ethnohistory 68:2 (2021). Diego Javier Luis, "The Armed Chino: Licensing fear in New Spain," Journal of Colonialism and Colonial History 20:1 (2019).

2. "En cuanto a la ciudad de Acapulco, me parece que debiera dársele más bien el nombre de humilde aldea de pescadores (tan bajas y ruines son sus casas, hechas de madera, barro y paja) que el engañoso de primer emporio del mar del Sur y escala de la China ... No habitan por ello más que negros y mulatos (los nacidos de negros y blancas) y muy raramente se ve algún nativo del lugar.” Giovanni Francisco Gemelli Careri, Viaje a Nueva España (Mexico City: Universidad Nacional Autónoma de México, 1983), 7-8. Unless stated otherwise, all translations are my own.

3. Giovanni Levi, "Frail Frontiers?" Past \& Present 242:14 (2019): 38-46. 
from the global dynamism of transpacific trade. ${ }^{4}$ Writing these histories will ultimately uncover and define what constituted the early modern Black Pacific. ${ }^{5}$ Alex R. Mayfield and Luz Alejandra Cárdenas Santana have offered important re-readings of Acapulco that accurately recharacterize it as a predominantly Afro-Mexican town during the seventeenth century. ${ }^{6}$ I argue that Black spiritualists practicing creolized medicine and magic were as fundamental to the lived experience of global Acapulco as the goods that came off the ships. The galleons were more than just conduits of labor, silk, and silver; they were fundamental to the production of knowledge. ${ }^{7}$

The Manila galleons traversed the most dangerous trade route of the early modern world, and they frequently succumbed to unruly seas. And yet, Acapulco's economic viability depended on their timely arrival. For most of the year, the port's anxious inhabitants watched the blue horizon and waited for any news of ship sightings from up the coast. During the early seventeenth century, in the absence of any indication of the galleon's arrival, a cohort of Afro-Mexican women offered the salve of information. They practiced divination and clairvoyance to predict the location and arrival of the galleons. More than mere superstitions and witchcraft, these women articulated a diasporic and socially mobile identity that reoriented spiritual authority and therefore gendered agency at the port.

Thus, the boom-bust realities of life in Acapulco exceeded the therapeutic capacities of Catholic dogma and at the same time gave rise to heterodox spiritual authorities capable of mobilizing Spanish folk traditions, Indigenous spiritualities, and West and West Central African ritual. ${ }^{8}$ Most often, these leaders were Afro-Mexican women, which signals, on one hand, the understudied and yet fundamental importance of transpacific travel to the Black communities of Mexico's Pacific coast and, on the other, how Black women in such communities responded with innovation to a rapidly globalizing colonial world. This article tracks the port's development as a predominantly Black and

4. Notable earlier studies include Rainer F. Buschmann, Edward R. Slack Jr., and James B. Tueller, Navigating the Spanish Lake: The Pacific in the Iberian World, 1521-1898 (Honolulu: University of Hawai'i Press, 2014); and Giráldez, The Age of Trade.

5. For an analysis of the contemporary Black Pacific, see Robbie Shilliam, The Black Pacific: Anti-Colonial Struggles and Oceanic Connections (New York: Bloomsbury, 2015).

6. Alex R. Mayfield, "Galleons from the 'Mouth of Hell': Empire and Religion in Seventeenth Century Acapulco," Journal of Early Modern Christianity 5:2 (2018): 231; Luz Alejandra Cárdenas Santana, "Lo maravilloso y la vida cotidiana. Mujeres de origen africano en Acapulco, siglo XVII,” Desacatos 9 (2002).

7. Dana Leibsohn and Meha Priyadarshini, "Transpacific: Beyond Silk and Silver," Colonial American Review 25:1 (2016): 9

8. Mayfield, "Galleons from the 'Mouth of Hell," 236; Joan C. Bristol, Christians, Blasphemers, and Witches: Afro-Mexican Ritual Practices in the Seventeenth Century (Albuquerque: University of New Mexico Press, 2007), 7; Gonzalo Aguirre Beltrán, Medicina y magia. El proceso de aculturación en la estructura colonial, 3rd ed. (Mexico City: Instituto Nacional Indigenista, 1987), 264. 
therefore socially transgressive space, the dynamism of which produced the first mention of using divination to locate a galleon, in 1584 .

This article benefits from a rich scholarship, pioneered by Gonzalo Aguirre Beltrán, that foregrounds Africans and Afro-descendants as generative forces in colonial societies of the circum-Caribbean and New Spain. ${ }^{9}$ Showing them to be more than purely reactive subjects locked into a frame of oppression and resistance, scholars like Pablo Gómez have argued that enslaved and free Africans quickly adapted to colonial realities of the Caribbean tropics and highlands of Central Mexico. ${ }^{10}$ Afro-Mexicans accumulated juridical knowledge and linguistic proficiencies, formed maroon communities, founded religious confraternities, negotiated complex social hierarchies, experimented with local pharmacological cultures, and joined and led vibrant spiritual practices. ${ }^{11}$ In ports, Indigenous towns (pueblos de indios), urban centers, mining colonies, plantations, and on mule trains en route to distant outposts, Africans and Afro-descendants unquestionably shaped the fabric of daily life in colonial Latin America. ${ }^{12}$ Locating Acapulco within this exciting scholarship highlights the port's prevailing importance during the eight months (or so) outside the trade season - the time of year colonial administrators designated the site as an intolerably unproductive and inhospitable backwater. From April to December, most of Acapulco's residents engaged with diverse multiethnic traditions that thrived beyond the Catholic church's narrow frame of acceptable religiosity.

This article begins by considering the intersections of labor demands and social demographics at the transpacific port. The insalubrity of the site, colonial expectations of lucrative trade, and a majority Black population marked Acapulco as a transgressive space. Within this context, I examine how anxiety about the galleon's arrival gave rise to specific practices of divination and clairvoyance. Equally significant are the practitioners themselves and how they mobilized mixed spiritual knowledge to address the unique therapeutic needs of the port town. In so doing, I connect gendered West Central African divinatory customs and Indigenous pharmacology to the emergence of 1972)

9. Gonzalo Aguirre Beltrán, La población negra de México, 2nd ed. (Mexico City: Fondo de Cultura Económica,

10. Pablo F. Gómez, The Experiential Caribbean: Creating Knowledge and Healing in the Early Modern Atlantic (Chapel Hill: University of North Carolina Press, 2017), 3-7, 117-120, 147. Also see Maureen Warner-Lewis, Central Africa in the Caribbean: Transcending Time, Transforming Cultures (Kingston: University of the West Indies Press, 2003), xxx; and Robert Farris Thompson and Joseph Cornet, The Four Moments of the Sun: Kongo Art in Two Worlds (New Haven, CT: Eastern Press, Inc., 1981).

11. Frank T. Proctor III, "Damned Notions of Liberty": Slavery, Culture, and Power in Colonial Mexico, 1640-1769 (Albuquerque: University of New Mexico Press, 2010), 71-91, 130-150.

12. María Elisa Gutiérrez Velázquez, Mujeres de origen africano en la capital novohispana, siglos XVII y XVIII (Mexico City: Instituto Nacional de Antropología e Historia, 2006), 24; Robert C. Schwaller, Géneros de Gente in Early Colonial Mexico: Defining Racial Difference (Norman: University of Oklahoma Press, 2016), 189-199. 
creolized Afro-Mexican spiritual communities in Acapulco. This analysis relies primarily on Inquisition denunciations and witness testimony. Though highly mediated texts, they nonetheless provide a window through which to examine otherwise undocumented social and cultural phenomena of New Spanish society. ${ }^{13}$

Acapulco was undeniably an epicenter of some of the most important developments in early modern global history, from unprecedented material exchange to transpacific mobility. Amid the hustle and bustle of loading and unloading the ships, other significant happenings transpired in the homes of free Black innkeepers, on nearby plantations, and on the quiet streets after nightfall. Both free and enslaved Africans and Afro-descendants like Tomas Mandinga, Cathalina Gonzalez de Santiago, Juana Moya, Cecilia, and numerous others accused of witchcraft (brujeria and hechiceria) and divination dominated daily spirituality at the port. ${ }^{14}$ With a couple of exceptions, all were women, socially mobile, and free.

By forming new solidarities around their spiritual knowledge, some women became visible and widely respected members of the port community. They enacted rituals involving cracking eggs into water, consuming the Indigenous hallucinogen ololiuhqui, creating love potions with herbs and menstrual blood, and using clairvoyance to ascertain the location of distant ships, whose position in the world's largest ocean was unknown. Their practices synthesized and adapted Afro-diasporic beliefs with origins in numerous African cosmological system, primarily West Central African, from the Bakongo and Mbundu peoples. They provided a necessary spiritual sustenance to the port town that it could not acquire through its limited Catholic presence and ceremonies. These individuals were innovators and collaborators, and their influence and knowledge typified life at the eastern edge of the Spanish Pacific world.

\section{ANXiety in ACAPulco, AN AFro-MeXican Port TOWN}

A yearly volley of one to two galleons from Cavite, near Manila, would typically arrive sometime between December (during a good year) and February or March (during a bad year). They often failed to show up entirely. Those that did had often sustained considerable damage and loss of life. In 1613, the crown estimated that it had lost eight million pesos in ships and goods to the

13. Laura A. Lewis, Hall of Mirrors: Power, Witchcraft, and Caste in Colonial Mexico (Durham: Duke University Press, 2003), 187.

14. When using names and terms derived directly from colonial-era sources, I have maintained the original orthography. 
tumultuous Pacific, just since $1602 .^{15}$ Each sunken ship represented hundreds of deaths by drowning. Crews, passengers, and residents on both sides of the Pacific lived with these grisly possibilities.

As they crept south along the Mexican coast, galleons that survived the crossing stopped in Navidad, several days' sail north of Acapulco, where they would unload a messenger (gentilhombre) to announce their arrival and any urgent news. Reports from scouts further up the coast, along with these messengers, would be the first notices of the galleon's arrival to reach the viceregal capital, Mexico City. ${ }^{16}$ Church bells would toll across the city in a gesture of thanksgiving. Once the galleon anchored in Acapulco, another messenger would ride swiftly to announce its formal arrival at port, upon which the church bells in the capital would ring out again. ${ }^{17}$ These were moments of spectacular celebration.

The most prolific early-mid colonial period diarists of Mexico City (Domingo Francisco de San Antón Muñón Chimalpahin Quauhtlehuanitzin, Gregorio Martín de Guijo, and Antonio de Robles) obsessively recorded the comings and goings of these galleons, the news they carried, the notable characters disembarking, and the state of transpacific trade. ${ }^{18}$ As early as 1574, Mexico City's cosmopolitan elite had begun marveling at the quantity, quality, and variety of Chinese goods available in the city. ${ }^{19}$ Bernardo de Balbuena delivered the best-known and most elegant stanzas on the transformative quality of the galleons on Mexico City culture and identity in his Grandeza mexicana (1604). Concluding his praise of transpacific trade, he wrote, "Mexico to the world equally divides/ and like the sun the earth to it inclines/ and in all it seems that it presides/. . . With all it trades and corresponds/ And at its shops stores and warehouses/ the best of these worlds flows." ${ }^{20}$ From the comfort of the viceregal capital, the galleons represented opulence, luxury, and grandeur. The material cultures they seeded formed a uniquely New Spanish colonial identity

15. Propuesta de nueva ruta de Filipinas a Nueva España, 1613, Archivo General de las Indias [hereafter AGI], Filipinas 329, leg. 2, fol. 170r.

16. See the reproduction of Adrian Boot's lithograph "Puerto de Acapulco en el Reino de Nueva España en el Mar del Sur" in Leibsohn and Priyadarshini, "Transpacific," l-2.

17. Giráldez, The Age of Trade, 136.

18. Don Domingo de San Antón Muñón Chimalpahin Quauhtlehuanitzin, Annals of His Time: Don Domingo de San Antón Muñón Chimalpahin Quaubtlehuanitzin, James Lockhart, Susan Schroeder, and Doris Namala, eds. and trans. (Stanford: Stanford University Press, 2006); Gregorio Martín de Guijo, Gregorio M. de Guijo diario, 1648-1664, vol. 2, Manuel Romero de Terreros, ed. (Mexico City: Editorial Porrúa, 1952); and Antonio de Robles, Diarios de sucesos notables (1665-1703), vol. 1 (Mexico City: Editorial Porrúa, S.A., 1946).

19. Meha Priyadarshini, Chinese Porcelain in Colonial Mexico: The Material Worlds of an Early Modern Trade (Cham, Switzerland: Palgrave Macmillan, 2018), 8.

20. "Mexico al mundo por ygual diuide/ y como a vn Sol la tierra se le incline/ Yen toda ella parece que preside/... Con todos se contrate y se cartea/ Y a sus tiendas bodegas y almazenes/ Lo mejor destos mundos acarrea." Bernardo de Balbuena, Grandeza mexicana (Mexico City: Diego Lopez Daualos, 1604), 75-78. 
and imaginary. The strength of the metropole depended on the galleons' arrival. But this was only part of the story.

Both Spanish secular and ecclesiastical authorities considered port cities to be notorious sites of spiritual infraction. They were contact zones, entrepôts of notable social diversity, from taverns of blasphemous sailors to the warehouses of wealthy merchants. ${ }^{21}$ As the crossroads through which Spain traveled to the Indies, Seville was the epicenter of the picaresque tradition, inspired by its seedy underworld of thrill-seekers, contrabandists, pickpockets, and globetrotters. ${ }^{22}$ In particular, the Triana neighborhood boasted an international multiethnic community of dockworkers and sailors who manned the galleons departing every year for the Americas. ${ }^{23}$ These seamen were the "fex maris (dregs of the sea)," rabble-rousers and miscreants, among whom loose words and looser breeches could consistently be found. ${ }^{24}$ Acapulco's history and demographics exacerbated this perception of ports as both socially and culturally subversive.

Spanish settlement at Acapulco dates to a simple shipyard operation in 1528. The site was strategically desirable for both the safety and depth of its harbor, which was such that ships could be moored by tying them to trees by the waterside. ${ }^{25}$ This undertaking would grow into a small town by 1550, on the backs of enslaved Indigenous and African laborers. After Acapulco attained the monopoly on transpacific trade in 1573, Spaniards began mobilizing enslaved Africans in larger numbers to travel into the hot lowlands to service the ships and attend to sailors and passengers. ${ }^{26}$ The "extreme heat" reflecting off the mountains into the basin, the poor soil, and the lack of fresh water meant that Spaniards considered enslaved Africans uniquely suited to labor in this harsh terrain. $^{27}$

This influx of bondsmen and women coincided with the years of the Iberian Union (1580-1640) and the Portuguese asiento (monopoly) in 1595, both of which significantly increased the numbers of enslaved Africans disembarking at

21. Mary Louise Pratt defines "contact zones" as "social spaces where cultures meet, clash, and grapple with each other, often in contexts of highly asymmetrical relations of power." Pratt, "Arts of the Contact Zone," in Profession (1991), 34; Pablo E. Pérez-Mallaína, Spain's Men of the Sea: Daily Life on the Indies Fleets in the Sixteenth Century (Baltimore: Johns Hopkins University Press, 1998), 237.

22. Elizabeth Nash, Seville, Córdoba, and Granada: A Cultural History (Oxford: Oxford University Press, 2005), $4-5$.

23. Pérez-Mallaína, Spain's Men of the Sea, 15.

24. Giráldez, The Age of Trade, 139.

25. William Lytle Schurz, "Acapulco and the Manila Galleon," Southwestern Historical Quarterly 22:1 (1918): 19.

26. Matthew J. Furlong, "Peasants, Servants, and Sojourners: Itinerant Asians in Colonial New Spain, 1571-

1720," (PhD diss.: University of Arizona, 2014), 463; Mayfield, "Galleons from the 'Mouth of Hell,” 231.

27. Schurz, "Acapulco and the Manila Galleon," 22. 
New Spain's Atlantic-facing port, Veracruz. Over 84 percent of the legally registered enslaved were West Central Africans, identified at the time as primarily from Angola, Congo, Benguela, Anchico, and Malemba. ${ }^{28}$ According to Pablo Sierra Silva, "a West Central African captive headed to Nueva Veracruz would spend approximately ten weeks within a given slave ship," though, he notes, the journey could last as long as 15 weeks in unruly seas. ${ }^{29}$ These men, women, and children quickly outnumbered the Senegambian enslaved African population that predominated in New Spain during the mid sixteenth century. ${ }^{30}$

The Portuguese Luis Mendes de Vasconcelos's war against the Ndongo from 1618 to 1621 resulted in a spike in West Central African captives and corresponded to the most intense period of slave trading to New Spain. ${ }^{31}$ Diasporic identities tended to cluster around shared linguistic and cultural traits across Bantu-speaking West Central Africa. ${ }^{32}$ Over time, the Black population in New Spain eventually transitioned into an increasingly American-born, mixed, and free demographic with extensive networks in enslaved, Indigenous, and mixed communities. As Afro-Mexicans poured into Acapulco, they became the largest population sector and easily outnumbered the Spaniards who remained during the off-season-a mere 70 in 1622. Simultaneously, the Indigenous population faced the ravages of disease, forced labor, and displacement, and by 1643, tributaries in Acapulco had declined to $185 .^{33}$

Once a galleon had successfully navigated the Boca Chica channel to anchor at port, the Afro-Mexicans of Acapulco crowded onto launches pushing off the beach toward the sea-worn vessels. They transported crates upon crates of valuable silks, ceramics, textiles, and furniture. They accompanied enslaved Asians (called chinos upon arrival) and East Africans en route to be sold. They escorted dying sailors (mostly Filipinos), the exiled, grateful missionaries, administrators, and petitioners ashore. ${ }^{34}$ Survivors of the passage rushed to the Hospital de Nuestra Señora de la Consolación or to mass at the parish church if

28. Frank T. Proctor III, "African Diasporic Ethnicity in Mexico City to 1650," in Africans to Spanish America: Expanding the Diaspora, Sherwin K. Bryant, Rachel Sarah O’Toole, and Ben Vinson III, eds. (Urbana: University of Illinois Press, 2012), 58.

29. Pablo Miguel Sierra Silva, "The Slave Trade to Colonial Mexico: Revising from Puebla de los Ángeles, 15901640," in From the Galleons to the Highlands: Slave Trade Routes in the Spanish Americas, Alex Borucki, David Eltis, and David Wheat, eds. (Albuquerque: University of New Mexico Press, 2020), 79.

30. Sierra Silva, "The Slave Trade to Colonial Mexico," 76-77; Paul Lokken, "West Central Africans in the Province of Guatemala, 1605-1655," in From the Galleons to the Highlands,” Borucki, Eltis, and Wheat, eds., 106.

31. John K. Thornton, Warfare in Atlantic Africa, 1500-1800 (London: University College London Press, 1999), 102; Pablo Miguel Sierra Silva, Urban Slavery in Colonial Mexico: Puebla de los Ángeles, 1531-1706, (New York: Cambridge University Press), 112.

32. Velázquez, Mujeres de origen africano, 74 .

33. Mayfield, "Galleons from the 'Mouth of Hell," 231.

34. Giráldez, The Age of Trade, 140-141. 
they were able. ${ }^{35}$ Black innkeepers and laborers profited from their monopoly on hospitality and services (and the desperation of sailors and travelers) to charge exorbitant rates for housing, portage, and water. ${ }^{36}$ As they acquired their freedom, Black women with years of experience in service and domestic settings gradually came to control these critical industries. From Acapulco to Callao, the labor of both enslaved and free Africans and Afro-descendants made ports and trade along Spanish America's Pacific coasts economically and infrastructurally viable. ${ }^{37}$

The castellan of the Fort of San Diego would similarly rush to sequester sailors' trunks and confiscate the goods of those who had perished at sea. ${ }^{38}$ Seeking fortune, hundreds, if not thousands, converged on the port: muleteers, merchants, friars, beggars, and enslaved retinues. ${ }^{39}$ The trade even brought unique opportunities to socially mobile Afro-Mexicans like Juan de Zaldívar, who by 1642 had accumulated an estate of over 12,000 pesos operating a mule train across the rugged highlands separating Veracruz and Acapulco. ${ }^{40}$

Gemelli Careri's surprise at discovering the quantity of "dark mulattos" in Acapulco was not exceptional. ${ }^{41}$ The world-traveling Spanish missionary Pedro Cubero reported in his Peregrinacion del Mvndo (1682) that Acapulco's "residents [habitadores] are negros, like Cafres [kaffirs, East Africans]." Cubero's identification of negros with cafres is a sure reference to the influx of enslaved East Africans displaced through the Indian Ocean world and sent to Acapulco for sale in Central Mexico. Though few in number during the seventeenth century, their presence was especially pronounced around the turn of the eighteenth century after the formal ban on transpacific slave trading of Asians to the Americas in 1672 left East Africans as virtually the only enslaved passengers aboard the Manila galleons. ${ }^{43}$

35. Mayfield, "Galleons from the 'Mouth of Hell," 238.

36. Tatiana Seijas, "Inns, Mules, and Hardtack for the Voyage: The Local Economy of the Manila Galleon in Mexico," Colonial Latin American Review 25:1 (2016): 67-68; Sarah E. Owens, "Crossing Mexico (1620-1621): Franciscan Nuns and Their Journey to the Philippines," The Americas 72:4 (2015): 595.

37. Rachel Sarah O'Toole, "Securing Subjecthood: Free and Enslaved Economies within the Pacific Slave Trade," in From the Galleons to the Highlands, Borucki, Eltis, and Wheat, eds., 149.

38. Carta de Corcuera sobre visita obispo, naos a Acapulco, 1636, AGI, Filipinas, 8, R.3, N.37; Orden de dar buen trato a marineros, 1660, AGI, Filipinas, 341, L.6, fols. 240v-24lv.

39. Schurz, "Acapulco and the Manila Galleon," 32.

40. Solange Alberro, Inquisición y sociedad en México, 1571-1700 (Mexico City: Fondo de Cultura Económica, 1988), 498.

41. Schurz, "Acapulco and the Manila Galleon," 32.

42. "sus habitadores son negros, a manera de Cafres." Pedro Cubero Sebastián, Peregrinacion del Mvndo (Naples: Carlos Porfile, 1682), 389.

43. For more, see Orden sobre esclavos que llegan a Acapulco desde Filipinas, 1700, AGI, Filipinas, 332, L.10, fols. 140v-142v; and Autos del galeón Nuestra Señora del Rosario del cargo de Miguel de Elorriaga," 1712, AGI, Contaduría, 908, N.1. 
Acapulco's Afro-Mexican population tended to live concentrated in a neighborhood called the Barrio de Guinea. ${ }^{44}$ They were the porters, dockworkers, enslaved servants and laborers, innkeepers, healers, and cowboys (vaqueros). ${ }^{45}$ During Carnival, after the mule trains laden with Asian goods departed, Gemelli Careri wrote:

Negros, mulatos, and mestizos of Acapulco, after eating, ran Parejas [pairs] with more than 100 horses and so well, that it seemed that they surpassed by far the great [horsemen] that I had seen run in Madrid . . . It is not a myth that those negros ran an Italian mile, grasping each other by hand or embraced, without ever separating themselves or splitting up in that whole space. Others at a gallop picked up a hat on the ground. ${ }^{46}$

During the seventeenth century, animal herding, riding, and caretaking had become distinctly Afro-Mexican professions, from agricultural estates to the bullfighting of Mexico City. ${ }^{47}$ Such communities were often known for rituals of divination and good fortune closely tied to Indigenous pharmacology and mixed-tradition spiritualities. ${ }^{48}$

Observations of large Black populations in New Spain fed into a discourse of fear around their perceived allegiance (or lack thereof) to colonial authorities. For example, a decree from 1578 described negros, mulatos, and mestizos as "universally inclined to evil."49 In 1608, many of Mexico City's Black "residents participated in a mock 'coronation' of a black king and queen," sparking a full investigation into an alleged conspiracy to displace Spanish colonial authorities. ${ }^{50}$ These tensions in the viceregal capital reached a feverish pitch after an abusive enslaver murdered an enslaved African woman at the end of 1611 and over a thousand Afro-Mexicans protested her death. By 1612, Spanish hysteria produced the condemnation of 28 men and seven women for alleged conspiracy against the colonial regime. The denounced hanged publicly; 29 of the 35 were subsequently decapitated and the other six quartered. ${ }^{51}$

44. Furlong, "Peasants, Servants, and Sojourners, 468. "Guinea" here does not refer to ethnicity or even a specific geographic region, but all of Africa.

45. Mayfield, "Galleons from the 'Mouth of Hell," 240.

46. "negros, mulatos y mestizos de Acapulco, después de comer, corrieron Parejas con más de cien caballos y tan bien, que me pareció que superaban en mucho a los grandes que yo había visto correr en Madrid . . . No es una fábula que aquellos negros corrían una milla italiana, sujetándose algunos por la mano y otros abrazados, sin separarse nunca o descomponerse en todo aquel espacio. Recogían otros al correr el sombrero del suelo.” Gemelli Careri, Viaje a Nueva España, 13 .

47. François Chevalier, Land and Society in Colonial Mexico: The Great Hacienda, Alvin Eustis, trans. (Berkeley: University of California Press, 1963), 112-113.

48. Aguirre Beltrán, Medicina y magia, 113.

49. Lewis, Hall of Mirrors, 98.

50. Camilla Townsend, Fifth Sun: A New History of the Aztecs (New York: Oxford University Press, 2019), 185.

51. Townsend, Fifth Sun, 186-187. 
Contributing to Spanish anxieties at the port were the forzados (multiethnic convict laborers) sent nearly every year to Acapulco for deportation to the Philippines. Stephanie Mawson calculates that New Spanish officials deported an average of 48 forzados via Acapulco each year during the seventeenth century. ${ }^{52}$ Forzados were typically poor Spaniards and mixed individuals, taken for criminals, sexual deviants, and vagabonds. They sometimes escaped en route to Acapulco, marking the road north to Mexico City as a space of subversion and transgression that officials attempted to curb through aggressive urban planning and customs checkpoints. ${ }^{53}$ The brutality of the journey from Mexico City to Acapulco frequently produced flight from bondage and blasphemy as protest. The 1612 case of the forzado Francisco de Santiago, a mulato from Abrantes in Portugal, is indicative. His ride on muleback was evidently so painful that, by the time he reached Tixtla (halfway), he could not but renounce God. ${ }^{54}$ On the same trip, another forzado, Melchor Gomez, escaped to an Indigenous town near Puebla but was captured and imprisoned. ${ }^{\mathbf{5 5}}$ Efforts to curb infractions on the road amounted to little, as the testimony of Joseph Ventura, an enslaved mulato of Taxco, attests. In 1700 at the Omitlan River, just east of the official route, Ventura came across a dark (prieto) mulato named Antonio Santiago, who offered him an herb with the power to sleep with any woman. When Ventura refused, Santiago threatened to kill him. ${ }^{56}$

The limited missionary presence in Acapulco did little to ameliorate spiritual infractions. Although the town swelled with a seasonal influx that ranged from 22 to as many as 142 zealous missionaries and clergy en route to Asia, few remained during the off-season. ${ }^{57}$ Those who did heard sporadic reports of troubling behavior and disturbances against the strictures of Catholic faith. For example, by 1590 an old Spaniard named Pedro de Balmaceda acquired a reputation as a seducer of married women. ${ }^{58}$ Sailors regularly blasphemed, like Antonio de Herrera, a Portuguese sailor who in 1604 was so distraught by the pelagic traumas of the Pacific passage that, upon arrival, he tried to kill himself. While recovering in the home of Ysabel Muñoz (morena), he said to two Spanish sailors that "God died on the cross for the dark-skinned (prieto) and the

52. Stephanie Mawson, "Unruly Plebeians and the Forzado System: Convict Transportation between New Spain and the Philippines during the Seventeenth Century," Revista de Indias 73:259 (2013): 219.

53. Daniel Nemser, Infrastructures of Race: Concentration and Biopolitics in Colonial Mexico (Austin: University of Texas Press, 2017), 46-47; Gemelli Careri, Viaje a Nueva España, 15, 19.

54. Proceso contra Francisco de Santiago, mulato natural de Abrantes, porque al llevarlo forzado a Filipinas renegó de Dios, Mexico, 1612, Archivo General de la Nación [hereafter AGN], Inquisición, vol. 288, exp. 9, fols. 460, 467.

55. Testificacion contra Melchor Gomez de la Puebla (a) Galagatosa, por haberse jugado cuando iba a las galeras a China, Mexico, 1612, AGN, Inquisición, vol. 455, exp. 112, fol. 823.

56. Denuncias que se remiten del puerto de Acapulco, 1703, AGN, Inquisición, vol. 757, fol. 294r.

57. Mayfield, "Galleons from the 'Mouth of Hell," 233, 242.

58. Acusacion presentada por Juan de Escovedo contra Pedro de Balmaceda, por estar amancebado y seductor de mujeres casadas. Acapulco, 1590, AGN, Inquisición, vol. 213, exp. 23, s.f. 
white-skinned (blanco) and for the small (chico) and the big (grande)."59 Denunciations for such blasphemous pronouncements were, in fact, so common that they almost never proceeded to a full trial. Herrera was merely ordered to confess to the vicar, which he seems to have evaded by returning to the galleon.

Cases of transpacific bigamy were not uncommon as well. In 1609, a chino named Agustin married a mulata in Colima, but another chino living in Chacala along the Colima coast testified that Agustin had already married his aunt in the Philippines. ${ }^{60}$ In 1648, a Dominican missionary overheard the watchman of a Manila galleon bragging to two sailors that he had married twice: first in Spain and then to an Indigenous female leader (india principala) in the Visayas, Philippines. ${ }^{61}$ As a final example, in 1669 a Filipino servant named Baltazar Melchor married an enslaved mulata of his employer's estate (bacienda) named Bernarda de los Reyes. However, many Black innkeepers in Acapulco had heard from numerous Filipino sailors staying with them that Melchor had already been married in Lolo, in Cagayan, Philippines, to a Fulana Sinio. ${ }^{62}$ As in many cases of transoceanic bigamy, the Inquisition failed to verify if the overseas spouse was still alive and so did not punish.

Inquisition records make clear that spiritual infractions in Acapulco's multiethnic community were common, but as we first learned from Gemelli Careri and Cubero, it was the Afro-Mexican population that caused officials and travelers the most worry. In 1660, a Captain Pablo de Carrascosa informed the Inquisition in an alarmed letter that "the largest part of the citizens [pecinos] of this port [Acapulco] [are] dark people [gente parda], mulatos, and negros" and that they did not obey ecclesiastical reprobation (censuras) to return stolen property "due to ignorance or extreme malice." 63 The response ordered negros, mestizos, and mulatos to obey the censuras under threat of excommunication and 200 lashes. "People of better quality [calidad] and Spaniards" would receive a fine of 200 pesos and temporary exile. ${ }^{64}$

59. "Morena" was a softer term than negra, often used by socially mobile Afro-Mexicans to distance themselves from a term that automatically implied slavery. Sierra Silva, Urban Slavery, 11; Testificacion contra Antonio Herrera, por judaizante (su prisión en Acapulco), 1604, AGN, Inquisición, vol. 368, exp. 115, fol. 451r.

60. Denuncia contra unos chinos uno de ellos llamado Agustin, por suspechas de casado dos veces, Tancitaro, 1609, AGN, Inquisición, vol. 285, exp. 61, fol. 258.

61. Autos contra Juan Martin, Guardian de la Nao N.S. de la Encarnacion, que llego este año de Filipinas, por bígamo, Acapulco, 1648, AGN, Inquisición, vol. 431, exp. 7, fols. 249-258. fol. 5 .

62. Proceso y causa criminal contra Baltazar Melchor, chino, por casado dos veces, Acapulco, 1669, vol. 612, exp. 4,

63. "la maior concurrencia de los vessinos de este puerto [son] gente parda mulatos y negros." Miguel de Loreto denuncia al santo tribunal el poco caso que hacen de las censuras de la iglesia los vecinos de Acapulco, Acapulco, 1660, AGN, Inquisición, vol. 439, exp. 20, fols. 124r-126r.

64. "que examinare si fueren negros mestizos y mulatos además de imponerles pena de excomunión se le podrá ordenar se les imponga también de doscientos azotes . . . y si fueren personas de mejor calidad y españoles de 200 p 
It was precisely the simultaneous obsession with the arrival of the galleons, fear of Afro-Mexicans, the vibrant culture of port-related infractions, and multiethnic convergence that ultimately created the demand and the supply for the teeming world of ship clairvoyance and divination that dominated the social culture of the port during the early-mid seventeenth century. A handful of Afro-Mexican women placed themselves at the nexus of this dynamic activity.

\section{The Vitality OF Divination}

The colonial economy of Central Mexico depended, in large part, on the successful arrival of the galleons, and Acapulco was no exception. Desperate for information on a ship's location, the port's residents frequently turned to Afro-Mexican healers and diviners for otherworldly information. Clairvoyance expresses both the tenuousness of early modern life in a port dependent on long-distance trade and the spiritual vitality that salved such anxieties.

By the early seventeenth century, Spanish men and women in Central Mexico regularly approached Indigenous and Afro-Mexican diviners for remedies to life's woes. ${ }^{65}$ Indeed, as María Elena Martínez writes, "The linkage of persons of African ancestry with occult practices and in particular with the Devil was one of the main tropes of Spanish colonial racial ideology." 66 Major sites of Afro-diasporic and creolized spirituality like Veracruz had already caught ecclesiastical attention for the fame of their practitioners. A "professional witch" like Leonor de Islas in New Spain's Atlantic-facing port combined Indigenous pharmacology and knowledge with West and West Central African ritual. ${ }^{67}$ Doing so presented no cosmological contradiction, and indeed, differentiating Indigenous and African spiritual practices in these sources is "notoriously difficult" as, often, all are simultaneously present. ${ }^{68}$ Becoming a spiritual authority represented an inversion of gendered colonial agency, "a way to survive in an increasingly cash-oriented economy," and a global convergence of spiritual intellectualism. ${ }^{69}$

As an example, the testimony of Ana Maria Vazquez (negra libre criolla) against Veracruz innkeeper Adriana Ruiz de Cabrera (negra libre criolla) described a

\footnotetext{
[eso]s y destierro.” Miguel de Loreto denuncia al santo tribunal el poco caso que hacen de las censuras de la iglesia los vecinos de Acapulco, Acapulco, 1660, AGN, Inquisición, vol. 439, exp. 20, fol. 126r. 65. Lewis, Hall of Mirrors, 118-122.

66. María Elena Martínez, "The Black Blood of New Spain: Limpieza de Sangre, Racial Violence, and Gendered Power in Early Colonial Mexico," William and Mary Quarterly 61:3 (2004): 511.

67. Alberro, Inquisición y sociedad en México, 487.

68. Lewis, Hall of Mirrors, 150.

69. Lewis, Hall of Mirrors, 110-123.
} 
ritual divination to locate a thief using seawater, green herbs, and paper with ritual markings like rhumb lines (raias, números, y estrellas al modo de una carta de marear). Although the Inquisition ultimately discarded Vazquez's denunciation in the face of Cabrera's overtures of Hispanicization, the use of water and herbs to discover a criminal is precisely the work of the Bakongo nganga-sènso (spirit medium with a pot). ${ }^{70}$ The reference to sacred script that appeared like rhumb lines is a likely reference to the dikenga (also called Twendwa kia Nza-n'kongo, or the Four Moments of the Sun), a Kongo cosmogram used in divination, which appears as "four cardinal points at the tips of two lines arranged in cross formation, similar to a compass." "71 Read counter-clockwise, it symbolizes continuing cycles of death and rebirth, with the vertical Mukula line signifying the transfer of knowledge from the world of the dead to that of the living. Such Afro-diasporic adaptations would reemerge and develop in distinct ways in response to Acapulco's galleon anxiety during the early seventeenth century.

The first reference to ship divination in Acapulco dates to 1584. An enslaved bozal (recently arrived, considered unassimilated) negro named Tomas Mandinga, 70 years old, acquired a reputation in Acapulco for curing the enslaved, Indigenous peoples, and Spaniards with roots and herbs. He testified that he would use "guayacan de ginea. . . which is of his land" by chewing and cooking it to cure. ${ }^{72}$ Among his powers, he successfully predicted that the "Cacao ship" (from Peru) would arrive soon "and it happened that it entered in under four or five days."73 This prediction coincided with the early growth of a hemispheric economy driven by wealthy Limeño investment in trade with Acapulco to access Asian wares. ${ }^{74}$

On another occasion, when asked when ships would arrive in Acapulco, he answered that the ships would not come because they were at "Concorate Beach." ${ }^{75}$ His ability to divine the location of ships en route to Acapulco even extended to individuals on those ships. A Spaniard, Diego Núñez de Sevilla, once asked when his daughter, Maria de Celada, would arrive in Acapulco. Tomas Mandinga answered only that Celada would not arrive in a frigate

70. Kimbwandende Kia Bunseki Fu-Kiau, African Cosmology of the Bântu-Kôngo: Principles of Life and Living, 2nd. ed. (New York: Athelia Henrietta Press, 2001), 124.

71. Bárbaro Martínez-Ruiz, Kongo Graphic Writing and Other Narratives of the Sign (Philadelphia: Temple University Press, 2013), 68-71; Thompson and Cornet, The Four Moments of the Sun, 43.

72. "que es de su tierra." Proceso contra Francisco de Arocha y Melchor Perez Morillo, cirujano, vecinos de Acapulco por fingirse ministros del Santo Oficio, Acapulco, 1584, AGN, Inquisición, vol. 213, exp. 7, s.f.

73. "navío de cacao," "fue que entro dentro de quatro o cinco dias." Proceso contra Francisco de Arocha y Melchor Perez Morillo, 1584, AGN.

74. William Lytle Shurtz, "Mexico, Peru, and the Manila Galleon," The Hispanic American Historical Review 1:4 (1918): 394-402.

75. I have not been able to locate this place: "plaia de concorate." Proceso contra Francisco de Arocha y Melchor Perez Morillo, 1584, AGN. 
(fragata) but in a larger ship. Although we have no information about specific rituals, Tomas Mandinga's powers brought together a diverse community desperate for information about maritime arrivals. He supplied answers, and accurately. An old man, Tomas Mandinga allegedly passed on his knowledge to a Lucia Mandinga, possibly a relative.

Although the presence of an ethnonym may not indicate more than colonial stereotypes about African peoples and geographies, Tomas's transfer of knowledge to Lucia may have followed traditions identified with the Mandinka, a construction of peoples who had migrated west from former centers of the Mali Empire. ${ }^{76}$ Female Mandinka specialists in magic and divination were called nieguanmuso and were regularly consulted after natural disasters and moments of misfortune. ${ }^{77}$ Perhaps Tomas recognized Lucia as a transatlantic nieguanmuso and appropriate bearer of divination and healing knowledge.

As the port became more enmeshed in a burgeoning transpacific economy, those who could procure information on the galleons rose to prominence. During the 1620s, several Afro-Mexican sorceresses caught the attention of Acapulco's residents and ecclesiastical authorities, at the same time that Black women elsewhere had begun to appear at disproportionate rates in Inquisition cases for divination, healing, and witchcraft. ${ }^{78}$ The timing also coincides with the most intense period of slave trading to New Spain and the demographic shift from an Indigenous to a West Central African and Afro-descendant population in Acapulco. $^{79}$

That Black women came to supply answers to the port's most pressing questions was no accident. West Central African communities held transatlantic gendered traditions that transplanted into New Spanish culture. Women were considered pillars of their communities. They safeguarded life as mothers and guardians in the worlds of both the living and the dead. ${ }^{80}$ They were often initiated alongside men as banganga (spirit mediums, literal expert, singular nganga) after their first menstruation cycle, like the famous Kongolese Antonian, Doña

76. Over time, Mandinka also became a referent to spiritual specialists in the Americas. Velázquez, Mujeres de origen africano, 71-73; Paul Nugent, "Putting the History Back into Ethnicity: Enslavement, Religion, and Cultural Brokerage in the Construction of Mandinka/Jola and Ewe/Agotime Identities in West Africa, c.1650-1930," Comparative Studies in Society and History 50:4 (2008): 934; Matt Schaffer, "Bound to Africa: The Mandinka Legacy in the New World," History in Africa 32 (2005): 329-330.

77. Velázquez, Mujeres de origen africano, 83.

78. Noemí Quezada, "The Inquisition's Repression of Curanderos," in Cultural Encounters: The Impact of the Inquisition in Spain and the New World, Mary Elizabeth Perry and Anne J. Cruz, eds. (Berkeley: University of California Press, 1991), 41-42.

79. Martínez, "The Black Blood of New Spain," 504.

80. Thompson and Cornet, The Four Moments of the Sun, 125-126. 
Beatriz Kimpa Vita, in the late seventeenth century. ${ }^{81}$ As mothers, they could acquire the title ngudi nganga (mother spirit medium), and were masters of the spirit world. ${ }^{82}$ Banganga served as healers, mediators, and problem-solvers for both individuals and their communities, investigating social and economic matters just as they would heal a patient. ${ }^{83}$

Healing rituals revolved around balancing one's fortunes and misfortunes to restore health to a state of order and harmony. Actualizing these ideals required knowledge of ritualistic purification, divine mediumship, trances, dream interpretation, animal sacrifice, and divine invocation through music, talismans, charms, and fetishes (minkisi in Kikongo). ${ }^{84}$ For example, mediumistic practices of Luunda and Yaka divination conjured ngoomb (ancestral spirit) to provide consultations and solutions to balance fortunes. ${ }^{85}$ Knowledge transfer of divinatory rites often occurred through ancestral, matrilineal inheritance and the bangudi banganga (pl.) who presided over initiation. ${ }^{86}$ Practitioners or priests were known as xingila in Kimbundu and as nganga ngombo (spirit medium or diviner) in Kikongo. The effectiveness of cures and prognostications gave legitimacy to the practitioner. ${ }^{87}$

During the late sixteenth century, both male and female banganga rose to prominence in the Kingdom of Ndongo under the reign of Ngola Kilombo kia Kasenda (r. 1575-92), who relied on spirit mediums for protection and advice. $^{88}$ It was his daughter, Queen Njinga Mbande (r. 1624-63), however, who became the example par excellence of a powerful female Mbundu diviner. According to the Italian Capuchin missionary Giovanni Antonio Cavazzi da Montecuccolo, Queen Njinga practiced sacrifice, prognostication, divination, and transformation into animals, and held diviners in such esteem that obeying and honoring them was the 13th of 14 sacred kijila (precepts) she kept and

81. John Thornton, The Kongolese Saint Anthony: Dona Beatriz Kimpa Vita and the Antonian Movement, 1684-1706 (New York: Cambridge University Press, 1998), 54-57.

82. Ras Michael Brown, "Mother Nganga: Women Experts in the Bantu-Atlantic Spiritual Cultures of the Iberian Atlantic World," in Women of the Iberian Atlantic, Sarah E. Owens and Jane E. Mangan, eds. (Baton Rouge: Louisiana State University Press, 2012), 208-209.

83. Thompson and Cornet, The Four Moments of the Sun, 111-113.

84. John K. Thornton, Africa and Africans in the Making of the Atlantic World, 1400-1600 (Cambridge: Cambridge University Press, 1992), 242-243; Herman L. Bennett, Colonial Blackness: A History of Afro-Mexico (Bloomington: Indiana University Press, 2009), 32, 75-76; Proctor, "Damned Notions of Liberty," 47, 77.

85. Javier Villa-Flores, "Talking through the Chest: Divination and Ventriloquism among African Slave Women in Seventeenth-Century Mexico," Colonial Latin American Review 14:2 (2005): 304-305.

86. Filip De Boeck and Marie-Françoise Plissart, Kinshasa: Tales of the Invisible City (Leuven: Leuven University Press, 2014), 115; Brown, "Mother Nganga," 209.

87. Thornton, Africa and Africans, 243, 247. $16-34$

88. Linda Heywood, Njinga of Angola: Africa's Warrior Queen (Cambridge: Harvard University Press, 2017), 
enforced. ${ }^{89}$ In the Americas, women with divinatory and healing knowledge led cults of ritual sacrifice, hallucinogenic consumption, spiritual possession, healing, love magic, protection, and of course, numerous forms of divination and clairvoyance. Continuing and adapting such practices in the Americas was fundamental to community and the construction of authority among marginalized and enslaved peoples. ${ }^{90}$

The first denunciations against Afro-Mexican women in Acapulco came against a Cecilia (negra) laboring in the Hospital Real. We know about these women because an inquisitor named Antonio Gutiérrez arrived in Acapulco in 1621 after reading reports that "the priests of the port too easily absolved cases of witchcraft." Gutiérrez was particularly concerned with collecting testimony from both the previous several years and the years of his tenure about women diviners who conjured, practiced mediumship, and hallucinated. ${ }^{91}$ In 1617, an old Spaniard, Domingo de Alberias, had testified that Cecilia gave him unusually specific information when he asked her about the Manila galleons. As a woman in the employ of the Hospital Real, she would have had regular access to sailors and travelers staying there during the trade season, as well as to the ecclesiastical community tending to the hospital and moving through its social circles. As such, she participated in Acapulco's hospitality sector, which free Black women had come to control from at least $1584 .{ }^{92}$ In response to the old Spaniard's query about the galleons, Cecilia said that the almiranta (vice-flagship) was lost at sea without mast and the sailors dead, which turned out to be true. ${ }^{93}$

In 1620, during a quiet evening, Cecilia had noticed that the Dominican missionary Domingo Martinez wandered about, upset that the galleons were late. To console him, she said, "Child (bijo), do not be sad. Two ships are coming, and they left from the Philippines." Surprised, the Dominican asked why the ships were taking so long. Cecilia replied, "Because the pilot was new on the route, he gave little sail and navigated little." Martinez asked if many had died. Cecilia said, "Many of the cabin boys [grumetes] who had embarked had died." Finally, Martinez wondered if any of his religious order were coming. Cecilia replied that she "had not noticed so much as that." The wife of

89. Giovanni Antonio Cavazzi da Montecuccolo, "Missione evangelica al Regno de Congo," Book 2.8, John K. Thornton, trans., Boston University, http://www.bu.edu/afam/people/faculty/john-thornton/john-thorntons-africantexts/, 101, 103.

90. Kathryn Joy McKnight, "Confronted Rituals: Spanish Colonial and Angolan 'Maroon' Executions in Cartagena de Indias (1634), Journal of Colonialism and Colonial History 5:3 (2004): not paged.

91. "los sacerdotes del Puerto absolvieran con mucha facilidad los casos de hechicería." Santana, "Lo maravilloso y la vida cotidiana," 82 .

92. Proceso contra Francisco de Arocha y Melchor Perez Morillo, 1584, AGN.

93. Denuncia contra una negra llamada Cecilia, porque anuncia las llegadas de las naos adivinando con exactitud las mas veces (Adivinacion), Acapulco, 1621, AGN, Inquisición, vol. 335, exp. 102, fols. 380-383. 
a ship captain also reported that Cecilia told Martinez that the capitana (flagship) would arrive before the almiranta, due to the pilot's inexperience. ${ }^{94}$

This conversation exemplifies the therapeutic structure of ship divination for anxious port inhabitants. It further inverts, genders, and racializes the father-son framework of Catholic ritual and rhetoric. The Manila galleons failed to arrive in 1619, inciting the Dominican Martinez to worry about the fate of his colleagues returning from far-off lands. The progression of questions leaned towards specificity, beyond simply if the ships would arrive or not. The limit of Cecilia's clairvoyance came when Martinez asked if Dominicans were aboard; she could not reassure him, although she had seen that cabin boys (predominantly Filipinos) had died. Her answers were direct, her language motherly_recalling the functions of the ngudi nganga - and her clairvoyance taken to be true. The captain's wife reported that Cecilia gave the same answer that year to many others who approached her with questions. The apparent inaccuracy of her 1620 prediction evidently did not tarnish her reputation, since her answers were considered correct most of the time. Although Cecilia was also known for divining the location of hidden or buried treasure and familiarity with rock idols (perhaps references to stone spirits known as bisembi and bankita), it was divining the position and state of the Manila galleons that gave her public renown in Acapulco. ${ }^{95}$

Cecilia also occasionally collaborated with the other Afro-Mexican women denounced for divination and clairvoyance during the same years. ${ }^{96}$ During the $1620 \mathrm{~s}$, an interconnected group of Black women gained notoriety for their healing and divination. The apparent ringleaders were the cousins Cathalina Gonzalez de Santiago and Isabel de Urrego, free mulatas, though Santiago was both a citizen of the port and slave owner as well. In their circle were Juana Maria (negra and morena), Madalena (enslaved mulata), Juana Moya (mulata), and Sebastiana Juarez (española [Spaniard]), with several other mulata and india collaborators. These women supported each other materially with herbs, socially with secrecy, and spiritually with guidance and solutions. They frequently spent time out of the port town in el monte (un-Hispanicized land) and a place across the bay called Icacos.

94. "hijo no tengas pena, que dos nauios vienen y salieron de las philippinas," "porque el piloto era nuebo en la carrera, daba poca vela y navegaba poco," "muchos de los grumetes que se auian embarcado se auian muerto," "no hauer reparado en tanto como esso.” Denuncia contra una negra llamada Cecilia, Acapulco, 1621, AGN.

95. Testificacion contra Domingo de Asturias, porque para descubrir minas se vale de hechicerías (Descubrimiento de minas por hechicerías), Acapulco, 1622, AGN, Inquisición, vol. 342, exp. 5, fol. 319; Warner-Lewis, Central Africa in the Caribbean, 170.

96. Santana, "Lo maravilloso y la vida cotidiana," 79-81. 
These women adapted their spiritual and material lives to the realities of the galleon trade. For example, Santiago once swallowed an entire nutmeg (imported from the Spice Islands), passed it, cleaned it, and put it in the daily chocolate drinks of men. She also used dog semen and menstrual blood in her chocolate-drink love magic potions. ${ }^{97}$ Juana Maria was known for her connection to animals and insects-including keeping a live caiman under her bed-and in 1607 had been seen with a beetle that was "very large and seemed nothing like those from here." The beetle had apparently been brought live from the Philippines on a galleon, and Juana Maria ate it to treat heart trouble (mal de corazón), implying knowledge exchange and an informal economy between her and Filipino sailors. ${ }^{98}$ These intellectual and experiential convergences typified Afro-Asian encounters in New Spain. ${ }^{99}$

Occasionally, the women sought to seduce transient sailors, as Isabel de Urrego did to Pedro Juarez from Peru. She had him ingest her cooked menstrual blood in his chocolate drink and buried three of his hairs, wrapped in special leaves from a nearby lake, at his door, so that "he would never leave the said Isabel de Urrego." 100 Using love magic to make a temporary relationship permanent was another form of spiritual therapy for galleon-induced anxiety.

Although Cathalina Gonzalez de Santiago was not known primarily for divining the location of the Manila galleons, she did so on at least one occasion. In 1618, Santiago performed a dance at her cousin's house with several other women in the presence of a cooper (tonelero) named Andres Garcia and others. The testimony does not reveal the dance's purpose, but the Afro-Atlantic context suggests spirit mediumship. After performing the dance, Santiago said, "Women, take ease. Two ships are coming, one big and one small." Her prediction "happened later." ${ }^{\prime 101}$ Like Cecilia, Santiago's answers followed in West Central African mediumship traditions of giving brief and direct answers during divination queries. ${ }^{102}$ Since the galleons of 1617 failed to arrive, 1618 was an anxious year for the port. The galleons would have to arrive to maintain the port's

97. Informacion contra Catalina Gonzalez, Isabel Urreso y Juana Maries, por brujas (Brujas) Acapulco, 1621, AGN, Inquisición, vol. 343, exp. 23, fol. 145r.

98. "muy grande y nada parecido a los de por acá." Informacion contra Catalina Gonzalez, Isabel Urreso y Juana Maries, por brujas (Brujas), Acapulco, 1621, AGN, Inquisición, vol. 343, exp. 23, fol. 150. We do not know what Juana Maria planned to do with the caiman, but it is worth noting that Cavazzi recorded that crocodile skins had sacred beauty in West Central Africa. Cavazzi, "Misione evangelica," 80

99. Luis, "Diasporic Convergences," 292-295.

100. Informacion contra Catalina Gonzalez, Isabel Urreso y Juana Maries, por brujas (Brujas), Acapulco, 1621, AGN, Inquisición, vol. 343, exp. 23, fol. 150r.

101. "mugeres holgaos que vienen dos naos una grande y otra pequena," "sucedió despues." "Informacion contra Catalina Gonzalez, Isabel Urreso y Juana Maries, por brujas (Brujas), Acapulco,” 1621, AGN, Inquisición, vol. 343, exp. 23, fol. 149r.

102. Villa-Flores, "Talking through the Chest," 306-308. 
economic viability. Santiago's words undoubtedly fell on grateful ears, and her prediction spread widely through the port, even among the garrison stationed at the fort. ${ }^{103}$

The principal galleon seer connected to the group, though, was the enslaved mulata Madalena, who divined using an Indigenous spiritual hallucinogen called ololiuhqui. She was among the first Black women in New Spain to learn the ritual consumption of the drug from the Indigenous of Mexico. The name itself refers to the seeds of a species of morning glory, which were typically ground up, mixed with an alcoholic drink, and consumed in a private setting. According to Gonzalo Aguirre Beltrán, ololiuhqui usage in the 1620s was concentrated around Mexico, Taxco, Tepecuacuilco, Acapulco, and Chiautla. The seeds, when consumed properly, granted the omniscience of three Nahua gods commonly syncretized with the Catholic god, angels, and/or the Virgin Mary. ${ }^{104}$

As sometimes happened to other enslaved Africans or Indigenous peoples, Madalena's enslaver (a chino drummer in the garrison) requested she take ololiuhqui to divine the location of the Manila galleons that were expected that year. ${ }^{105}$ She said that two were coming. A second instance of clairvoyance provides more details. Juana Manuel, a mulata, had need for love magic and divination and so procured ololiuhqui seeds from a Spanish ship-caulker and his wife, who had bought them from a Francisca Bula negra. Juana Manuel then brought the seeds to the local ololiuhqui specialist, Madalena, who had arranged for the group to use a front-room in her enslaver's house for the ritual, around 9 or $10 \mathrm{pm}$. Madalena made an ointment from the ololiuhqui, which she smeared all over Juana Manuel's chest and face; she then had her drink the rest with the express purpose of divining the location of the ships expected from the Philippines that year. Madalena then lit two wax candles and copal in front of an image of the Virgin Mary. She wrapped herself in a blanket in front of the image, where they were to wait for the spirit of an old indio who would answer all questions. A barking dog and noisy shingles seemed to have disrupted the ritual, and Juana Manuel either never received answers to her questions or refused to disclose more details to the Inquisition. ${ }^{106}$

103. "Informacion contra Catalina Gonzalez, Isabel Urreso y Juana Maries, por brujas. (Brujas) Acapulco," 1621, AGN, Inquisición, vol. 343, exp. 23, fol. 155r.

104. Aguirre Beltrán, Medicina y magia, 131-137.

105. Carta del Br. Melchor Annejo, Comisario del Santo Oficio en Acapulco devolviendo los edictos de la fe que se le enviaron y refiriéndose a Francisco Buli, negro, Catalina Xuarez y Francisco Lopez, por hechiceros. Acapulco, 1627, AGN, Inquisición, vol. 363, exp. 29, fol. 234r.

106. Carta del Br. Melchor Annejo, Comisario del Santo Oficio en Acapulco devolviendo los edictos de la fe que se le enviaron y refiriéndose a Francisco Buli, negro, Catalina Xuarez y Francisco Lopez, por hechiceros. Acapulco," 1627, AGN, Inquisición, vol. 363, exp. 29, fol. 236. 
Although incomplete, this syncretized consumption of ololiuhqui to conjure ancestral spirits for the purposes of divination is consistent with both Indigenous and nganga mediumship ritual practices at the time. ${ }^{107}$ Madalena's clairvoyance indicates the multiethnic context of non-dogmatic spiritual practices in Acapulco and, simultaneously, the multiethnic demand for knowledge of galleon whereabouts. Interest in the location of ships was not merely the purview of well-to-do Spaniards. The trajectory of maritime-inspired divination in Acapulco began with a recently arrived (bozal), an enslaved African, and culminated in a mixed Black woman's leadership in the cult of ololiuhqui. These shared traditions indicate multiethnic collaboration, knowledge production, and cultural exchange, all centered around the ships that connected Acapulco to Asia through Cavite and to South America through Callao.

According to ecclesiastical officials in 1621, "Nothing else is dealt with in this port." 108 Though many Spaniards and citizens made use of Afro-Mexican spiritual insight, at least one, Ursula Ome, was so scandalized that she called Juana Maria a "wicked witch": "There you will see this witch sorceress whore [puta bruja hechicera] who comes to soil me like the rest of her companions."109 The accusation targeted the women's sexual intimacies. Urrego had been seen seated among Juana Maria's skirts, placing food in her mouth, and "speaking to her affectionately" 110 Similarly, in 1627 when the Spaniard Francisca Lopez was on the verge of death, she called the port's alguacil mayor (chief constable) to her, begging him to not let Francisca Bula (negra), Sebastiana Juarez (española), Juana Maria (negra), an india, a Francisca de Rivera (mestiza of Peru), and Casilda (negra) near her because they were witches. ${ }^{111}$ Despite these testimonies and perceptions, none of the cases resulted in documented punishment and only one recommended punishment, against Juana Maria and Isabel de Urrego. ${ }^{112}$ Indeed, throughout the colonial period, women diviners tended to evade formal sentencing. ${ }^{113}$ Still, these women contributed to the religio-racial imaginary of the port as a zone of impurity, scandal, and corruption. It was, thus, not merely

107. Thornton, The Kongolese Saint Anthony, 54

108. "en este Puerto no se trata otra cosa." Informacion contra Catalina Gonzalez, Isabel Urreso y Juana Maries, por brujas (Brujas) Acapulco, 1621, AGN, Inquisición, vol. 343, exp. 23, fol. 157r.

109. "bellaca bruja," "ay veréis esta puta bruja hechicera que me viene a embarrar a mi como a las demás compañeras suyas.” Informacion contra Catalina Gonzalez, Isabel Urreso y Juana Maries, por brujas (Brujas), Acapulco, 1621, AGN, Inquisición, vol. 343, exp. 23, fol. 145r.

110. "hablándole cariñosamente." Santana, "Lo maravilloso y la vida cotidiana," 84.

111. Carta del Br. Melchor Annejo, Comisario del Santo Oficio en Acapulco devolviendo los edictos de la fe que se le enviaron y refiriéndose a Francisco Buli, negro, Catalina Xuarez y Francisco Lopez, por hechiceros, Acapulco, 1627, AGN, Inquisición, vol. 363, exp. 29, fol. 226.

112. Informacion contra Catalina Gonzalez, Isabel Urreso y Juana Maries, por brujas. (Brujas) Acapulco,” 1621, AGN, Inquisición, vol. 343, exp. 23, fol. 157r.

113. Villa-Flores, "Talking through the Chest," 308. 
demographics and climate that motivated Fray Domingo Fernandez Navarrete and his informants to imagine Acapulco as the "mouth of Hell."114

Still, more Spaniards and citizens took advantage of the spiritual prowess of these women than despised their non-dogmatic spirituality. Perhaps it was their regional influence and popularity that would inspire an old india zahori (clairvoyant and geomancer) to offer information about the Manila galleons in Tixtla in 1650. Using different techniques, the unnamed india arrived at similar answers to similar questions. She divined through the stars that two ships were coming. She said, "The one [ship] came tossed about with much risk of being lost the past January of this year," and that it "was on the coast of Zacatula" and would arrive in two weeks. On another occasion, she predicted that only one ship would come the first week of Quaresma. ${ }^{115}$ The india required money for the predictions and claimed that she called on God's aid for information. Given the trajectory of Afro-Mexican clairvoyance in Acapulco during the 1620s, this may be one of the few documented instances during the seventeenth century of an Indigenous woman participating in a spiritual economy first developed by Afro-Mexicans in New Spain.

Although ship divination ceased to be documented in Acapulco after the 1620s, diarists in Mexico City recorded its sporadic continuance in central Mexico during the second half of the seventeenth century. On Sunday, August 8, 1655, Gregorio Martín de Guijo logged the following:

and this day they say that the tribunal of the Inquisition imprisoned some mulatas who said that the fleet of San Lúcar [de Barrameda] had left for these lands on July 2, and that it would arrive safely at Veracruz, and that the two ships that had been dispatched for Spain had arrived safely at Havana, and the silver galleons of which there had been no news were anchored without risk, and that if this was not so, they [the mulatas] asked to be burned. They asked the tribunal for mercy (misericordia). ${ }^{116}$

Guijo's account described the mulatas as talented and confident ship-diviners who the Inquisition ultimately reduced to supplicants of God's holy mercy to absolve themselves of sin. Significantly, Guijo did not record any punishment and

114. Mayfield, "Galleons from the 'Mouth of Hell," 221.

115. Denuncia contra Maria de Solis, por haber preguntado a una india sahori si vendrían o no las naos filipinas, Tixtla, 1650, AGN, Inquisición, vol. 435, exp. 106, fol. 145.

116. "y este día dicen prendió el tribunal de la inquisición, unas mulatas que decían haber salido la flota de San Lucar para estos reinos a 2 de julio, y que llegaría a salvamento a la Veracruz, y que las dos naos que despacharon para España, habían llegado a la Habana a salvamento, y los galeones de la plata de que no se tenía noticia, estaban sin riesgo surtos, y que si esto no fuese así, pedían las quemasen. Pidieron misericordia al tribunal.” Guijo, Gregorio M. de Guijo diario, 28. "Galones de la plata" is vague phrasing and could refer to 1) ships from Peru arriving in Acapulco, 2) ships en route to the Philippines from Acapulco, or 3) ships leaving Veracruz for Spain. 
reproduced the prediction, eager as he characteristically was, for any news of maritime arrivals.

Guijo's discursive successor as diarist, Antonio de Robles, documented a similar occurrence in September of 1677: "These past days they say that the Inquisition arrested a sorceress (hechicera), who showed in a trough of water that eight ships of a fleet were coming and that they would arrive on the day of Saint Nicholas."117 Although Robles did not record ships arriving on Saint Nicholas's day that year, his account reinforces that ship divination had proliferated. Furthermore, Robles recorded the method, hydromancy, a common divination technique in New Spain, with both Indigenous and West Central African roots. ${ }^{118}$

The cases discussed here trend toward integration with burgeoning and adaptive spiritual cultures in New Spain. The rise of ololiuhqui among Afro-Mexicans, use of menstrual blood in love magic (popular in southern Spain), and the formation of multiethnic therapeutic communities, all signal a highly generative context of cultural exchange. ${ }^{19}$ Simultaneously, the matriarchal structure of magic and healing, specific divination knowledge, and experiential productivity, express a fundamental West Central African context that cannot be ignored in broader discussions of adaptive spirituality in New Spain.

No document informs us as to why these denunciations had largely disappeared in Acapulco by the second half of the seventeenth century. Blasphemy and bigamy among sailors and soldiers continued to typify Inquisition cases at the port, but sorcery and witchcraft would never return to the feverish pitch of the late sixteenth and early seventeenth centuries. One possibility is Acapulco's demographic transition from an Indigenous to a predominantly Afro-Mexican population. The heightened visibility of Black women in the port's public life as innkeepers, laborers, slaves, cooks, healers, and diviners left an imprint in the archival record, but once their presence had become more normalized, they no longer attracted such sustained inquisitorial scrutiny.

A second possibility lies in the cases' lack of resolution. I could find no evidence that these women received any punishment. Perhaps such activity became so common, influential, and necessary to public life that it simply ceased to be reported. In fact, Antonio Gutiérrez may have been the only inquisitor who

117. "Estos días atrás han dicho prendieron una hechicera en la Inquisición, que mostró en una batea de agua venían ocho navíos de flota y que vendría el día de San Nicolás.” Robles, Diarios de sucesos notables, 221.

118. Aguirre Beltrán, Medicina y magia, 28-29.

119. María Helena Sánchez Ortega, "Sorcery and Eroticism in Love Magic," in Cultural Encounters: The Impact of the Inquisition in Spain and the New World, Mary Elizabeth Perry and Anne J. Cruz, eds., 79-82; Ruth Behar, "Sex and Sin, Witchcraft and the Devil in Late-Colonial Mexico," American Ethnologist 14:1 (1987): 39, 48; Aguirre Beltrán, Medicinay magia, 116. 
cared to collect these testimonies in Acapulco. As an institution, the Inquisition had little time to prosecute and punish such frequently employed practices in smaller towns, especially as "la Gran Complicidad" (the Great Complicity) redirected attention toward alleged Judaizers during the 1640s. ${ }^{120}$

A third and final possibility regards the galleon routes. Officially sanctioned galleon travel between New Spain and Peru dropped off gradually during the first half of the seventeenth century because New Spanish prices were outcompeting Spanish goods arriving via Portobelo in Panama, inciting strict regulation. ${ }^{121}$ Although transpacific travel remained just as dangerous-if not becoming more so-during the latter half of the seventeenth century, it had ceased to be as much of a novelty. It was a reality of life.

The accumulation of these factors highlights that the aforementioned therapeutic solutions to galleon anxiety expressed localized and historically contingent spiritual responses to a rapidly globalizing world. Black women utilized both transatlantic and local ritual knowledge to create nodes of authority, exchange, and community that significantly elevated their reputations in an otherwise patriarchal and race-conscious society. What endowed them with influence was precisely the accuracy of their predictions. In the absence of any other way to pinpoint ship location, they were reliable enough to be trusted. In contrast to other instances of divination at the time, these women did not provide omniscient knowledge expressly for money. ${ }^{122}$ It is certain that money was exchanged, but I suspect that their primary currencies were authority, therapy, and favor.

In New Spain - a colony uniquely positioned to receive the riches of the Atlantic and the Pacific - it was not only material cultures, cartographies, and aristocratic worldviews that expressed global connectedness from this colonial core. In a backwater colony that supposedly came alive for only three or four months a year, several Afro-Mexican women-pejoratively termed 'witches'-created a local spiritual culture of ship clairvoyance, seduction, and healing that was deeply connected to New Spain's central role in the global transformations of the early modern world. Like the ngudi nganga, they healed not only individuals but also their communities, through knowledge of the spirit world. Though they have passed largely unnoticed until now, their lives, words, and actions are nonetheless essential for understanding how individuals and

120. Alberro, Inquisición y sociedad en México, 550-591.

121. Mariano Bonialian, China en la América colonial: Bienes, mercados, comercio y cultura del consumo desde México hasta Buenos Aires (Mexico City: Editorial Biblios, 2014), 53-54.

122. Joan Bristol, "Ana de Vega: Seventeenth-Century Afro-Mexican Healer," in The Human Tradition in Colonial Latin America, 2nd ed., Kenneth J. Andrien, ed. (Lanham, MD: Rowman \& Littlefield Publishers Inc., 2013), 210. 
communities of New Spain's Pacific coast imagined their locales as, for the first time, linked to far-off places, processes, and peoples.

Davidson College

DIEgo JAVIER LUIS

Davidson, North Carolina

diluis@davidson.edu 